\title{
A POUCA E MÁ FORMA NAS COUZAS DA FAZENDA REAL: CRISE ECONÔMICA E ARRECADAÇÃO NA CAPITANIA DA PARAÍBA NO GOVERNO DE JOÃO DA MAIA DA GAMA (1708-1717)
}

\author{
THE LITTLE AND BAD SHAPE IN THE FIELDS OF THE DEPARTMENT OF THE \\ ROYAL TREASURY: ECONOMIC CRISIS AND COLLECTION IN THE CAPTAINSHIP \\ OF PARAÍBA UNDER THE GOVERNMENT OF JOÃO DA MAIA DA GAMA (1708-1717)
}

\author{
Isabela Augusta Carneiro Bezerra*
}

\begin{abstract}
RESUMO
Aportando na capitania da Paraíba em um período de profunda crise econômica, o capitão-mor e governador João da Maia da Gama participou ativamente da administração colonial, traçando planos e estratégias nos campos político, econômico e militar. O presente artigo pretende analisar o seu desempenho na execução das atividades administrativas na capitaniadurante os anos de 1708 a 1717 -, especialmente suas ações no âmbito econômico e faẓndário; cotejar as práticas políticas do governador no exercício de seu cargo com as ordens e legislaçoes régias, observando seus limites jurisdicionais, a possibilidade de autonomia frente às diretrizes metropolitanas e possiveis tensões na relação entre poder central e poder local; bem como examinar, na própria órbita local, a existência de conflitos jurisdicionais nos quais João da Maia tenha se confrontado com outros agentes administrativos.
\end{abstract}

PALAVRAS-CHAVE: Administração colonial. Capitania da Paraíba. João da Maia da Gama. Século XVIII.

\begin{abstract}
Coming into port at the captainship of Paraiba in a period of profound economic crisis, the captain-major and governor of Paraiba João da Maia da Gama took part actively in the colonial administration, outlining plans and strategies in the military, economic and political fields. The present article intends to analyse his performance and the practices in the exercise of their governmental functions at the captainship - during the years 1708 to 1717 - especially the actions in the economic and finan environment, compare the political practices of the governor in the exercise of his office with royal orders and legislation, observing their juridic boundaries, the possibility of autonomy in face to the metropolitan guidelines and possible tensions in the relationship between central and local power, as well as examine, in the local orbit itself, the existence of jurisdictional conflicts in which João da Maia has faced other administrative agents.
\end{abstract}

KEYWORDS: Captainship of Paraíba. Colonial administration. João da Maia da Gama. $18^{\text {th }}$ century.

\footnotetext{
* Professora do Instituto Federal de Educação, Ciência e Tecnologia da Paraíba (IFPB). Mestra em História pela Universidade Federal da Paraíba (UFPB). Doutoranda em História Moderna pela Universidade de Coimbra, Porugal. E-mail: isabela_carneiro@outlook.com
} 


\section{INTRODUÇÃO}

Na primeira década do século XVIII, as capitanias do norte atravessavam uma difícil conjuntura econômica. Segundo Guillermo Palacios, a crise experimentada pela economia açucareira desde o fim do século XVII era composta, basicamente, por dois elementos. Por um lado, havia uma abrupta queda do preço do açúcar nos mercados europeus, oriunda do significativo aumento da oferta do produto, a partir do início da concorrência da produção das Antilhas holandesas, britânicas e francesas. Aponta o autor que os preços do açúcar no mercado de Lisboa passaram de $3 \$ 800$ réis, em 1654, para $1 \$ 300$ réis, em 1688. Após uma efêmera recuperação na década de 1690, o preço retorna à tendência declinante, baixando a arroba dos $2 \$ 400$ réis, atingidos em 1706 , para $1 \$ 600$ nos anos seguintes, mantendo-se flutuando entre $1 \$ 200$ e $1 \$ 400$ réis até praticamente a metade do século (PALACIOS, 2004, p. 44).

Por outro lado, ocorreu uma elevação do preço dos escravos durante a década de 1710, com taxas superiores a 5\% ao ano, originada pelo apogeu das recém-descobertas minas de ouro na parte central da colônia. A mineração passou a preponderar sobre as demais atividades econômicas, subordinando-as às necessidades demandadas pelo novo foco da economia colonial. De acordo com o historiador, estima-se que o preço de escravos nos portos nordestinos tenha saltado de 40 ou $50 \$ 000$ réis, em 1700, para 100\$000 réis em 1710 (PALACIOS, 2004, p. 44 e 51).

De acordo com Lopes, a capitania de Pernambuco, após sofrer uma certa recuperação econômica observada nas décadas de 1670 e 1680, voltou a sofrer impactos com a queda da economia açucareira a partir da década seguinte:

Na década de 1690, a crise parece pronunciar-se mais uma vez, quando menos, pelo aumento da concorrência do açúcar do Caribe produzido nas colônias inglesas, com o aumento da produção em Barbados, Jamaica e nas ilhas Leeward, que tomaram o espaço das reexportações portuguesas nos portos do Norte da Europa e, claro, na Inglaterra. Assim, a tendência de baixa no mercado açucareiro parece ter pesado mais fortemente sobre Pernambuco que sobre a Bahia na última década seiscentista (LOPES, 2012, p. 34).

$\mathrm{Na}$ verdade, desde o período pós-guerra holandesa, a Paraíba experimentava um momento de crise. As guerras de restauração contra o domínio holandês arremessaram a capitania em um estado de penúria e devastação econômica na segunda metade do século XVII. A resistência dos combatentes, com a queima de engenhos, currais de gado e lavouras, implicou a ruína de sua estrutura produtiva. Como assevera Menezes (2010, p. 41), pelo menos até meados da segunda metade do século XVIII, a economia permaneceu num "estado crônico de apatia profunda, em que a precariedade fora a regra." $O$ autor sintetiza as causas da crise:

A situação desvantajosa do comércio do açúcar no plano externo, provocada pela concorrência antilhana, baixando o preço do açúcar, aliada ao controle marítimo imposto pelos holandeses na África, cobrando $10 \%$ sobre qualquer transação, além 
da concorrência desleal dos mineiros na compra de escravos no Brasil, no plano interno, deixava a todos numa situação de penúria (MENEZES, 2010, p. 43).

Ao aportar na Paraíba em 1708, João da Maia da Gama deparou-se, portanto, com uma capitania economicamente fragilizada. Depois de quinze anos mergulhado em jornadas militares, o lusitano atingia as terras paraibanas a fim de exercer as funções para as quais havia sido designado pela realeza portuguesa: ser capitão-mor e governador da capitania da Paraíba, cargo que exerceria por três longos triênios (1708-1717). Os serviços militares empreendidos nos vários domínios do império português o habilitaram a ser agraciado com o governo da Paraíba, inaugurando em sua carreira uma dimensão inédita no âmbito da sua prestação de serviços à Coroa portuguesa.

Antes de assumir o governo da capitania, João da Maia prestou serviços militares na Índia, na África e na Guerra da Sucessão Espanhola (1702-1714). Após o término de sua gestão na Paraíba, em 1717, retornou a Portugal. Anos depois, em 1722, foi novamente recompensado pelos seus serviços, desta vez sendo nomeado como governador e capitão-general do Estado do Maranhão, cargo que ocuparia até 1728, quando então regressaria definitivamente ao reino (MARTINS, 1944).

A produção açucareira paraibana - conduzida, nas palavras do governador, por "miseráveis senhores de engenho" -, encontrava-se em crise, devido, sobretudo, à queda do preço do açúcar nos mercados europeus e da falta de escravos que assolava os engenhos paraibanos. Um novo arranjo econômico forjava-se no interior da colônia, fomentado pela exploração das recém-descobertas minas de ouro. A promissora atividade aurífera drenava a mão-de-obra escrava para a região das minas, agravando o estado de carência de negros nas capitanias do norte.

Despojados de escravos, os engenhos tornavam-se improdutivos, resultando em uma baixa produção de açúcar. Para complicar ainda mais o quadro, um prolongado período de seca (1710-1715) devastou as plantações de cana na capitania. A desfavorável conjuntura econômica incidia sobre a arrecadação tributária, pois a parca produção de açúcar atenuava os rendimentos da Fazenda Real da Paraíba. Ademais, havia os descaminhos provenientes da arrematação do contrato dos dízimos do açúcar, que sangravam a instituição.

Diante desse cenário de crise, que se perpetuou pelo início do século XVIII, João da Maia da Gama proporia e executaria algumas medidas para tentar dirimir o decadente quadro econômico da Paraíba durante sua gestão (1708-1717). A fim de minimizar o crítico quadro de escassez de escravos na Paraíba, articulou viagens à África para introduzir negros na capitania.

Em paralelo, o lusitano engendrou um estratégico combate à sonegação de impostos na capitania. Controlar os descaminhos provenientes da arrematação do contrato dos dízimos do açúcar foi um dos desafios encontrados por João da Maia no exercício de seu cargo, como veremos neste artigo.

${ }^{1}$ AHU_ACL_CU_014, Cx. 5, D. 360. Consulta do Conselho Ultramarino, ao rei [D. João V] 8/6/1717. 


\section{ARRECADAÇÃo DE TRIBUTOS NA PARAÍBA: A INGERÊNCIA DE JOÃo DA MAIA NOS (DES)CAMINHOS DOS NEGÓCIOS FAZENDÁRIOS}

A prática adotada pelas monarquias do Antigo Regime europeu, de conceder a particulares a prerrogativa de cobrar direitos, através de contratos que eram arrematados, foi transferida para as conquistas. Delegar a competência de natureza fiscal a particulares (um negociante ou uma sociedade deles) proporcionava certas vantagens à Coroa. Por isso, dificilmente ela coletava diretamente os tributos. A desoneração dos custos da montagem de um aparelho burocrático mais estruturado, capaz de executar e fiscalizar a cobrança de impostos por territórios geograficamente vastos e dispersos, era uma das vantagens. Outra consistia em assegurar antecipadamente um rendimento certo, fator que possibilitava um mínimo de projeção e planificação das despesas do reino (OSÓRIO, 2010, p. 109-110).

A crença na maior eficácia do sistema de arrendamento dos tributos pode ser vislumbrada na ordem régia de 4 de fevereiro de 1711, quando se instituiu a dízima da Alfândega, o mais importante imposto da capitania de Pernambuco no século XVIII, segundo Carrara (2011, p. 33). Tal ordem expressava que "por ter mostrado a experiencia, que arrendando-se por contracto estes direitos, ham de produzir muito mais, que administrando-se pela Fazenda Real.”2

Os contratos eram arrematados por intermédio de hasta pública. Nas arrematações, os negociantes pretendentes "lançavam", isto é, ofereciam seus lances pelo contrato. Em geral, cada contrato tinha duração de três anos, porém muitas vezes tinham sua vigência estendida para seis ou nove anos (OSÓRIO, 2010, p. 110).

De acordo com Menezes (2005, p. 116), a divulgação do processo de arrematação desses contratos podia ser realizada de duas formas: "por via impressa, através de editais pregados nos lugares públicos, ou por proclamação, com o meirinho saindo às ruas munido de um tambor, anunciando em pregão a abertura dos trabalhos." Decorrido um mês na capitania de origem, o processo seguia para a Provedoria-mor, na Bahia, onde os mesmos procedimentos seriam executados. Após recolhidos os lanços dessa praça, o arremate retornava à capitania inicial para ser posto em praça por mais um mês. $O$ contrato poderia ser feito ainda, em última instância, no próprio reino, através do Conselho Ultramarino.

Cabia ao maior licitante procurar recolher uma importância superior ao que apresentara como lance. Só assim realizaria uma transação lucrativa. Entretanto, quando a atividade não se revelava rentável aos interessados, a cobrança dos impostos executava-se através da própria Fazenda Real. Neste caso mais incomum, dizia-se que "o contrato estava sob administração" (PRADO JÚNIOR, 2000, p. 328).

Incidia sobre o contratador a obrigação de entregar carta fiança de $10 \%$, assinada por terceiros, garantindo, assim, o compromisso não apenas de saldar o valor do arremate, mas também de pagar todas as propinas aos oficiais que se beneficiavam com o processo. Em contrapartida, o contratador recebia um alvará que lhe assegurava a prerrogativa de nomear pessoas, em seu nome ou em nome do seu

2 ABN, vol. XXVIII, p. 287. Ordem régia 4/2/1711. 
procurador, para efetivarem o trabalho de cobrança, enquanto vigesse o contrato. Caso o prazo do contrato não fosse observado, a dívida deveria ser saldada pelo fiador (MENEZES, 2005, p. 117-118).

Os contratadores eram pessoas bem informadas quanto ao valor e volume da produção. Este conhecimento sobre a economia e a dinâmica local, sem dúvida, balizava o valor do lance por eles ofertado. Sobre o assunto, discorre Schwartz (2011, p. 154):

\begin{abstract}
O contratador tinha uma ideia aproximada da produtividade da região, mas não podia prever secas, inundações ou guerras. Ele tinha provavelmente uma capacidade muito melhor de estimar o preço dos principais gêneros produzidos. Sabia que se a produção dobrasse mas o preço caísse pela metade o valor do contrato não seria maior do que fora antes dessas alterações.
\end{abstract}

O lucro real obtido com a arrecadação dos contratos era ocultado pelos envolvidos. Somente o valor pelo qual o contrato fora licitado era de domínio público. A manutenção do segredo do negócio garantia a conservação da taxa de lucro, pois, caso esta fosse conhecida, implicaria na elevação proporcional do preço do contrato nas arrematações seguintes (OSÓRIO, 2010, p. 123). A expectativa de um exorbitante lucro animava os sujeitos a encararem esta transação de risco. De risco porque o contratador estava sujeito a imprevisíveis mudanças na economia, como calamidades naturais, guerras, invasões, desvalorizações da moeda e queda no preço dos produtos (MENEZES, 2005, p. 118).

A principal fonte de arrecadação colonial era o dízimo. Estava presente em toda a América portuguesa. "O dízimo era um imposto de um décimo de toda a produção pago à Igreja, mas no Brasil era arrecadado pelo monarca em sua condição de grão-mestre da Ordem de Cristo" (SCHWARTZ, 2011, p. 154). Até 1606, o contrato do dízimo foi arrematado em Portugal. Após essa data, passou a ser realizado no Brasil.

Embora, em geral, os contratos possuíssem vigência de três anos, na Paraíba do início do século XVIII, o contrato dos dízimos se arrematava anualmente. ${ }^{3} \mathrm{Na}$ capitania, o montante recolhido a partir dos dízimos destinava-se ao pagamento da folha eclesiástica e executiva, devendo o seu sobejo servir também para pequenas despesas da Provedoria da Fazenda Real e para o complemento da folha militar (MENEZES, 2005, p. 115).

Em 1710, o governador João da Maia da Gama relatou que, na época, os "mais modernos" contratos do dízimo do açúcar continham uma condição de dar praça aos açúcares procedidos do dízimo. Condição esta requerida por outros contratadores que ainda não tinham conseguido arrematar com a cláusula referida. ${ }^{4}$

Na verdade, esta nova condição havia sido implementada em 17 de agosto de 1706, por meio de carta régia endereçada ao capitão-mor da Paraíba, na qual se ordenava ao provedor da Fazenda da capitania que, a partir daquela data em diante, arrematasse o contrato dos dízimos reais com a condição

\footnotetext{
3 "O contracto dos Dízimos se aremata todos os annos, e não tem lançador senão de Junho por diante athe o fim de Julho, por q querem ver primeiro como corre o ano, e como sessem a canna, $\mathrm{p}^{\mathrm{a}}$ conforme a conveniencia q prometer, lançarem" (AHU_ACL_CU_014, Cx. 4, D. 332. Carta do [capitão-mor da Paraíba], João da Maia da Gama, ao rei [D. João V] 17/6/1712).

${ }^{4}$ AHU_ACL_CU_014, Cx. 4, D. 302. Auto de uma portaria do governador da Paraíba, João da Maia da Gama 1/4/1710.
} 
de se dar aos contratadores praça para os açúcares procedidos do dito contrato e não para outros que não tivessem essa natureza. ${ }^{5}$

Ademais, a designação régia previa que, caso o capitão-mor ou o provedor da Fazenda da capitania negassem as ditas praças aos contratadores, toda perda ou dano seria reparado através da execução dos bens das referidas autoridades: "quando vos, ou o ditto Provedor da Fazenda lhe negue a ditta Praça possa o contratador haver pellos bens de qualquer de vos q lha negar toda a perda e danno $\mathrm{q}$ receber em lhe faltarem as tais praças."6

Além deste privilégio da concessão de praças, mostrou João da Maia que gozavam os contratadores de outro direito: a isenção das caixas de açúcar do contrato do dízimo de qualquer tributação. Não pagavam o direito de subsídio do açúcar (\$60 réis por arroba do açúcar branco e $\$ 30$ réis do açúcar mascavado), nem o cruzado das caixas ( $\$ 400$ réis por cada caixa) para as fortificações, nem o antigo imposto de quatro vinténs (\$80 réis por caixa, sobre o açúcar exportado exclusivamente para o reino). ${ }^{7}$

Como bem elucida Helen Osório, o estabelecimento de privilégios mercantis para os contratadores era uma situação comum na realidade colonial. Os contratadores não lucravam somente com a diferença entre o preço fixado no contrato e o valor do produto arrecadado. "As cláusulas dos contratos lhes garantiam uma série de privilégios mercantis que permitiam sua atuação no mercado de forma diferenciada e monopolística" (OSÓRIO, 2010, p. 122). A concessão desses privilégios, considerados muitas vezes abusivos pelas autoridades e pela população, gerava um sentimento generalizado de antipatia em relação aos contratadores. Assinala Boxer (2010, p. 331):

Nada é mais característico do antigo império marítimo português do que as queixas constantes de seus habitantes sobre as atividades perniciosas dos monopolistas e açambarcadores. Essas queixas estendem-se, no tempo, da época do infante dom Henrique, o Navegador, até a de dom João VI, e, no espaço, das Molucas até Mato Grosso.

Dentre os monopolistas, encontramos justamente o grupo dos contratadores. Nesse sentido, a queixa endossada pelo governador da Paraíba era mais uma expressão que reverberava esse sentimento de hostilidade. Para João da Maia da Gama, a liberdade de qual gozavam os contratadores dos dízimos da Paraíba, de não pagar os impostos sobre as caixas de açúcar que serviriam para o pagamento do valor do contrato dos dízimos, era extremamente prejudicial à Fazenda Real, uma vez que concorria para limitação da sua receita. Nas suas palavras, "sendo o contracto dos dizimos e dirtos dos sucidios tudo de VMagde me parecia q os contratadores pagassem todos os dirtos dos asucres do seu contracto." 8

\footnotetext{
5 AHU_ACL_CU_014, Cx. 4, D. 323. Consulta do Conselho Ultramarino, ao rei D. João V 28/11/1710.

6 AHU_ACL_CU_014, Cx. 4, D. 323. Consulta do Conselho Ultramarino, ao rei D. João V 28/11/1710.

7 AHU_ACL_CU_014, Cx. 4, D. 302. Auto de uma portaria do governador da Paraíba, João da Maia da Gama 1/4/1710. Os três impostos elencados por João da Maia correspondem às taxas que incidiam sobre a exportação de açúcar. Estas tributações reservavam-se às obras da Fortaleza do Cabedelo, à folha militar e ainda auxiliavam no pagamento do governador (MENEZES, 2005, p. 115).

8 AHU_ACL_CU_014, Cx. 4, D. 323. Consulta do Conselho Ultramarino, ao rei D. João V 28/11/1710.
} 
Após relatar o caso em carta para o reino, João da Maia não apenas conseguiu com que fosse extinto o referido privilégio dos contratadores, como também recebeu aprovação e elogios dos conselheiros do Conselho Ultramarino. É o que podemos observar na consulta do dito Conselho de 1710:

Ao Conçelho pareçe que ao capitão mor da Parahiba, se deve agradeçer o zello em que se houve neste particular, recomendando se lhe continue com o mesmo daqui em diante, e que na arrematação do contracto que se fizer dos dízimos daquella capitania, findo o q corre, que se deve por a condição, de que os contractadores pagarão direitos dos asucres do seu contracto, porque por este caminho se evitarão muitos descaminhos, quaes reconheçe o capitão mor, que examinou este negoçio com toda a individuação, e exação. ${ }^{?}$

A liberdade dos contratadores não foi o único problema encontrado pelo governador na arrecadação dos dízimos. Parece que os privilégios outorgados aos contratadores não foram suficientes para satisfazer as ambições econômicas do grupo. João da Maia revelou um esquema através do qual os contratadores conseguiam lesar a Fazenda Real. Acontece que os contratadores costumavam embarcar as caixas de açúcar do contrato do dízimo sem passar no passo do Varadouro, minando qualquer tentativa de fiscalização das cargas dos navios e, por conseguinte, impossibilitando o recolhimento dos impostos devidos. A situação tornava-se ainda mais grave pelo fato dos mesmos contratadores colocarem, junto do encaixamento dos açúcares do contrato do dízimo, marcados com selo próprio, outras caixas de açúcar que não eram provenientes do mesmo contrato. Desta forma, partiam do porto todas as caixas livres da tributação real. ${ }^{10}$

Insatisfeito com os descaminhos observados no processo, João da Maia denunciou à Coroa as atitudes tomadas pelos contratadores e procurou remediar a situação, tomando medidas contra as práticas de sonegação. Por meio de portaria, solicitou que o desembargador Manoel Velho mandasse notificar os contratadores dos dízimos para que jurassem a quantidade de caixas de açúcar que possuíam dos contratos e que não as embarcassem e alterassem na última hora a carga dos navios, a fim de evitar que se carregassem outros açúcares que não fossem do contrato. E, ainda, que não se embarcassem as caixas sem antes ir aos passos, onde os fiéis do passo ou os oficiais de guerra, que o governador mandasse por nele, fariam uma vistoria e passariam um documento para as receberem nos navios. ${ }^{11}$

João da Maia ordenou que fossem notificados também os capitães e mestres de navios. Aos capitães dos navios designava que não recebessem, nem dos contratadores e nem de qualquer pessoa, as caixas de açúcar sem o documento dos passos. E que, ao despacharem a carga, fizessem uma lista arrolando todas as caixas e feixes embarcados para que se conferisse com o documento expedido dos passos. O governador acrescentou, ainda, que os capitães e mestres dos navios deveriam enviar uma via da dita lista dos açúcares embarcados ao Conselho Ultramarino para que, caso levassem mais alguma

9 AHU_ACL_CU_014, Cx. 4, D. 323. Consulta do Conselho Ultramarino, ao rei D. João V 28/11/1710.

10 AHU_ACL_CU_014, Cx. 4, D. 302. Auto de uma portaria do governador da Paraíba, João da Maia da Gama 1/4/1710.

11 AHU_ACL_CU_014, Cx. 4, D. 302. Auto de uma portaria do governador da Paraíba, João da Maia da Gama 1/4/1710. 
caixa além das contidas na lista, pagassem em dobro para Fazenda Real. Os capitães e mestres de navios ficavam também obrigados a entregar uma via da lista dos açúcares embarcados ao próprio governador. ${ }^{12}$

João da Maia da Gama, na conta que deu ao reino sobre a arrematação dos contratos dos dízimos, remeteu em anexo as listas dos açúcares embarcados no porto da capitania em 1710, no intuito de que, de posse delas, o provedor da alfândega pudesse conferir, na descarga dos navios, o número de caixas trazidas pelos mestres com a quantidade contida nas listas enviadas e que, caso houvesse mais caixas desembarcadas do que as dispostas nas listas, pagassem os responsáveis o prejuízo à Fazenda Real, conforme havia mandado notificar o próprio capitão-mor. ${ }^{13}$

Outra reclamação recaía ainda sobre os contratadores dos dízimos. Dessa vez, oriunda dos capitães e mestres dos navios. De acordo com estes, os contratadores retardavam o máximo para carregarem suas caixas nos navios,

[...] querendo ver se tinhão melhor preço os asucres ou se podião fazer negocio com as praças, querendo guardallas $\mathrm{p}^{\mathrm{a}}$ a ultima hora, o que he conhecido prejuízo dos officiaes dos navios e gente do mar, q como vendem com vagar as suas fazendas nos últimos da partida cobrão e comprão as suas cx ${ }^{\text {as }}$ e as embarcão nestas praças q os contratadores lhes querem tirar. ${ }^{14}$

Essa queixa foi encaminhada, através de requerimento, ao capitão-mor João da Maia da Gama, o qual proferiu a seguinte deliberação:

mandei noteficar aos contratadores e capes dos Navios, estes $\mathrm{p}^{\mathrm{a}} \mathrm{q}$ feito o porão não recebessem carga sem primr ${ }^{\circ}$ recolherem as do contracto aquelles $\mathrm{p}^{\mathrm{a}}$ jurarem as $\mathrm{q} \mathrm{cx}^{\text {as }}$ tinhão do contrato e porem nas promptas $\mathrm{p}^{\mathrm{a}}$ as embarcarem sob penna de perderem a liberdade q pella condição do contrato tem de se lhe darem praças. ${ }^{15}$

É interessante destacar que, neste episódio atrelado aos descaminhos e inconvenientes da arrecadação dos dízimos, o governador resolveu solucionar a incômoda situação antes de receber qualquer decisão régia. É o que observamos na carta de 5 de junho de 1710, quando João da Maia a encerra afirmando que "em q ${ }^{\text {to }}$ VMagde não detremina o q foi servido lhe pus o remédio que podia." $16 \mathrm{E}$ assim despachou ao reino a mencionada portaria, na qual mandava notificar os sujeitos envolvidos, além das também aludidas listas dos açúcares embarcados nos navios. Como vimos, sua atitude acabaria por render elogios e agradecimento do Conselho Ultramarino.

As medidas empregadas pelo governador surtiram o efeito desejado: promoveram um aumento flagrante na arrecadação do subsídio do açúcar, no ano de 1710. Segundo Menezes (2005, p. 127-128), o ano de 1710 configurou o pico de toda a exportação durante a primeira metade do século XVIII. O valor alcançado pela arrecadação foi 4:451\$775, conforme se pode observar na Figura 1:

12 AHU_ACL_CU_014, Cx. 4, D. 302.Auto de uma portaria do governador da Paraíba, João da Maia da Gama 1/4/1710.

13 AHU_ACL_CU_014, Cx. 4, D. 302.Auto de uma portaria do governador da Paraíba, João da Maia da Gama 1/4/1710.

14 AHU_ACL_CU_014, Cx. 4, D. 323. Consulta do Conselho Ultramarino, ao rei D. João V 28/11/1710.

15 AHU_ACL_CU_014, Cx. 4, D. 323. Consulta do Conselho Ultramarino, ao rei D. João V 28/11/1710.

16 AHU_ACL_CU_014, Cx. 4, D. 323. Consulta do Conselho Ultramarino, ao rei D. João V 28/11/1710. 
Figura 1 - Arrecadação do subsídio do açúcar (Primeira metade do século XVIII)

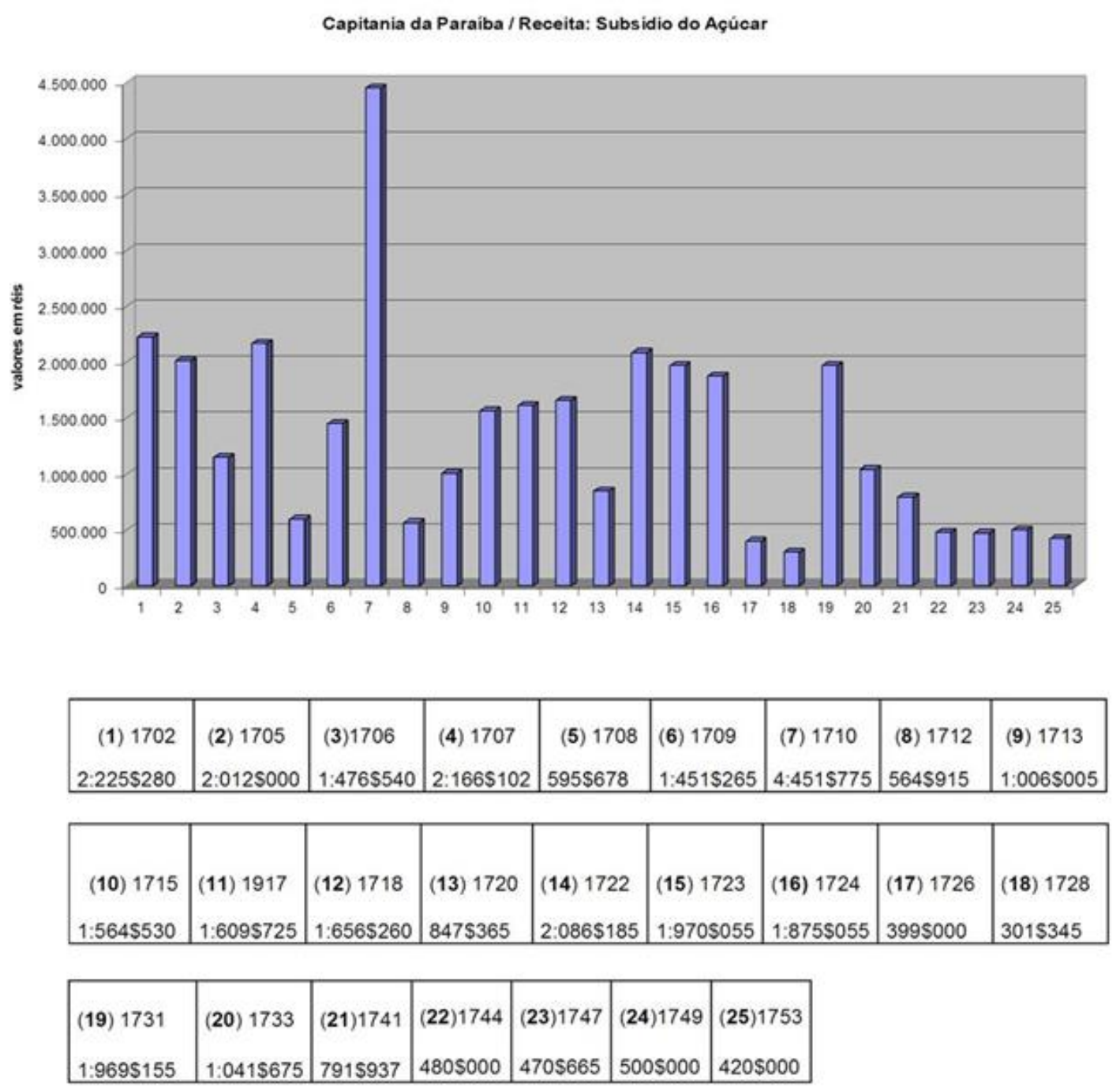

Fonte: Arquivo Histórico Ultramarino

Fonte: Menezes (2005, p. 127)

Duas razões garantiram o êxito: a quebra das liberdades dos contratadores dos dízimos e a primeira e bem sucedida venda acumulada do açúcar estocado nos passos paraibanos, na qual se pode dispor das sobras das caixas de açúcar oriundas das boas safras dos anos de 1706 a 1709, mesmo levando em conta a baixa do ano de 1708, quando somente um navio entrou no pouco visitado porto da Paraíba. Sobre o acúmulo de caixas não negociadas nos trapiches, escreve Menezes (2005, p. 126):

O ajuntamento das caixas de açúcar nos passos podia estar respaldado em três principais motivos: a) a insatisfação de algum senhor de engenho com o preço do açúcar; b) a crônica falta de navios nos portos paraibanos; e c) a carência da produção em si. O terceiro motivo, que parece mais plausível, acarretou uma política deliberada por parte da Fazenda Real, no sentido de resguardar a produção do açúcar, por alguns anos, como um meio de aumentar a receita e saldar dívidas atrasadas. 
A preocupação de João da Maia acerca da matéria tributária talvez se justifique pelo fato de os governadores receberem comissão sobre o valor dos contratos de arrematação de impostos, "regalia destinada a incentivar os governadores a fazerem subir os respectivos montantes", como aponta Mello (2003, p. 251). Em 1714, o próprio capitão-mor da Paraíba certificou, com desgosto, que recebia de propina apenas $80 \$ 000$ réis no contrato dos dízimos e nada mais em nenhum outro contrato. ${ }^{17}$

Nos anos posteriores, no entanto, a situação não seria nada animadora para a arrecadação do subsídio do açúcar. Acontece que uma prolongada seca, ocorrida entre os anos de 1710 e 1715, levou a uma grande diminuição do valor do tributo, tanto que, costumando render 4, 5 ou 6 mil cruzados, houve ano em que rendeu pouco mais de $300 \$ 000$ réis. A diminuição da arrecadação comprometeu o pagamento da infantaria. Em atraso, os soldos começaram a computar sempre um ano de dívida, gerando insatisfação nas tropas. Em função disso, em 1715, João da Maia remeteu ao reino um requerimento da infantaria, no qual solicitava que lhe pagassem os atrasados pelos efeitos da dízima - imposto destinado às fortificações - a fim de regularizar doravante a situação. ${ }^{18}$

Consultado o Conselho Ultramarino, a maioria dos seus membros posicionou-se favoravelmente à solicitação. Reconhecendo a guarnição dos soldados como mais importante que as fortificações para a defesa da Paraíba, o parecer considerou ser justo a satisfação dos soldos. Caso contrário, poderiam os soldados desertar do serviço de Sua Majestade. Desse modo, aconselhou que se suprisse o pagamento da infantaria com o empréstimo do rendimento da dízima, com a condição de "se restituir a mesma dízima tudo o q se tirar della $\mathrm{p}^{\mathrm{a}}$ este effeito das mesmas consignações dos subcidios e mais rendas aplicadas para a mesma Infantaria."19

Embora majoritário, o parecer não agradou o conselheiro José Carvalho de Abreu, cuja opinião apresentou individualmente. A seu ver, em todas as capitanias do Brasil existiam faltas nas consignações deputadas aos pagamentos dos soldados. Sendo assim, conceder a referida mercê à Paraíba poderia estimular que as demais capitanias, mirando-se neste exemplo, intentassem o mesmo, frustrando o fim para o qual a dízima foi imposta. Em seu despacho, D. João V seguiu a orientação do conselheiro. ${ }^{20}$

Em 1718, a situação perdurava. Nesse ano, os soldados da infantaria remeteriam novo documento ao reino, relatando que entravam no quinto ano de atraso dos seus soldos. ${ }^{21}$ De acordo com Salvador Quaresma Dourado, provedor da Fazenda da Paraíba, os soldos que iam vencendo não tinha como ser pagos a todos, pois os subsídios do açúcar - receita de onde se originava o pagamento dos soldados - "rendem tão pouco por cauza dos poucos asucares que tem feito esta Capitania, que há alguns annos não chegão, nem para pagar a metade da Infantaria, por estarem os engenhos mui desfabricados de escravos."'22

\footnotetext{
17 AHU_ACL_CU_014, Cx. 5, D. 342.. Carta do capitão-mor da Paraíba, João da Maia da Gama, ao rei [D. João V] 6/5/1714.

18 AHU_ACL_CU_014, Cx. 5, D. 353. .Consulta do Conselho Ultramarino, ao rei D. João V 22/2/1716.

19 AHU_ACL_CU_014, Cx. 5, D. 353. .Consulta do Conselho Ultramarino, ao rei D. João V 22/2/1716.

20 AHU_ACL_CU_014, Cx. 5, D. 353. .Consulta do Conselho Ultramarino, ao rei D. João V 22/2/1716.

${ }^{21}$ AHU_ACL_CU_014, Cx. 5, D. 366. Consulta do Conselho Ultramarino, ao rei D. João V 16/5/1719.

22 AHU_ACL_CU_014, Cx. 5, D. 362. Carta do [provedor da Fazenda Real], Salvador Quaresma Dourado, ao rei [D. João V] $12 / 8 / 1718$.
} 
As continuadas secas também abalariam a arrematação dos dízimos na capitania. Nas palavras de João da Maia da Gama,

Em o anno de 1710 p o de 1711 houve huma seca, a mais terrível q se lembrão os moradores desta Cap ${ }^{\text {nia }}$ de $\mathrm{q}$ morreo $\mathrm{m}^{\text {tos }}$ milhares de gado nesta Cap ${ }^{\text {nia }}$ pois houve fazenda q de 3 mil cabeças lhe não ficou mais q 600 e a mesma seca q houve pellos certões, houve por baixo pellos canaviaes, e os demais delles arderão, e as plantas secarão no q tiveram grandissima perda os contratadores daquelle anno. ${ }^{23}$

Em virtude da seca que atingiu os canaviais, não houve, em 1711, quem se lançasse no contrato dos dízimos do açúcar, passando meses na praça sem nunca passar de 6 mil cruzados. Diante de tal quadro de penúria, João da Maia relata, em carta enviada ao reino, que fez uma diligência com o empreiteiro Simão Gomes para crescer o valor do contrato. No acordo, Simão Gomes se obrigava a pagar $600 \$ 000$ réis (ou 1,5 mil cruzados), em dinheiro, acima do último lance dado no contrato. O valor seria quitado do seguinte modo: uma parte, 3 mil cruzados, seria dada em farda para os soldados; e o resto, 3 mil cruzados, em dinheiro, no valor que a Fazenda Real lhe pagasse pela obra que realizasse no forte de Cabedelo. No total, acrescido os $600 \$ 000$ réis que o empreiteiro se dispunha a pagar, o contrato atingia a soma de 7,5 mil cruzados. ${ }^{24}$

João da Maia mandou informar ao provedor da Fazenda o modo como havia ajustado com o empreiteiro a arrecadação do dízimo. O provedor, consultou o Procurador da Coroa, o qual alertou não se poder alterar a forma de arrematação do contrato sem ordem do monarca. ${ }^{25}$ Como indica Menezes (2005, p. 117), o pagamento dos valores acertados nesses contratos poderia ser repassado à Fazenda em açúcar, fazendas ou dinheiro. Essa era a forma costumeira.

Receber parte do pagamento dos dízimos em obras, por bem dizer, além de incorrer em inovação na arrematação, poderia não configurar um negócio tão benéfico à Coroa, pois, ao condicionar uma parte da importância ao dinheiro que o empreiteiro receberia da Fazenda Real pelo serviço que executasse em Cabedelo, a Coroa se via obrigada ou a fazer pagar a dita obra - pagamento que costumeiramente podia atrasar - ou a não receber o quartel referido do dízimo, arcando assim a Fazenda com a perda de 3 mil cruzados. Já Simão Gomes, com a manobra, garantia o direito de receber pelo trabalho que empreendesse no forte de Cabedelo.

Todavia, embora estivesse ciente do parecer desfavorável do Procurador da Coroa, o governador da Paraíba ordenou ao provedor da capitania que, não havendo quem superasse os 6 mil cruzados, arrematasse o contrato pelos 7,5 mil cruzados, na forma oferecida pelo empreiteiro Simão Gomes. Para justificar sua decisão, apresentou três argumentos: uma ordem real de 27 de agosto de 1709, na qual se proferia que "sempre será conveniente q o resto se pague a dinhro"; defendeu que a Fazenda Real não podia perder, sem prejuízo, os $600 \$ 000$ réis ofertados; e, por fim, apontou que se de

23 AHU_ACL_CU_014, Cx. 4, D. 329. Carta do capitão-mor da Paraíba, João da Maia da Gama, ao rei D. João V 27/5/1712.

${ }^{24}$ AHU_ACL_CU_014, Cx. 4, D. 329. Carta do capitão-mor da Paraíba, João da Maia da Gama, ao rei D. João V 27/5/1712.

${ }^{25}$ AHU_ACL_CU_014, Cx. 4, D. 329. Carta do capitão-mor da Paraíba, João da Maia da Gama, ao rei D. João V 27/5/1712. 
Pernambuco viesse o dinheiro que a Coroa mandava para as fortificações, o contrato seria pago antes do tempo, sem a espera das frotas e mais demoras com que se costumava arrematar. ${ }^{26}$

Os gastos financeiros despendidos pela provedoria de Pernambuco com as capitanias do norte eram constantes. Nas palavras de Menezes (2005, p. 66), “o epíteto de capitania-geral reconhecido entre as suas anexas e as correlações de força político-militares, anunciavam, também, a relação de dependência econômica do restante das capitanias para com a provedoria de Pernambuco." Dela provinham muitos dos recursos necessários para o andamento da vida administrativa nas capitanias, como o pagamento de clérigos e militares ou a manutenção e construção de fortalezas.

No caso específico da Paraíba, a dependência, na esfera econômica, em relação a Pernambuco era evidente. Desde o período pós-guerra holandesa, a Paraíba, em proclamado estado de miséria devido à devastação causada pelo combate, de modo recorrente buscava o auxílio financeiro de sua vizinha. Alguns documentos constatam essa situação.

Em 1655, o então mestre-de-campo João Fernandes Vieira, requeria que “em Pernambuco, lhe sejão pagos os soldos, que constar se lhe devem, e for vençendo na Parahiba [...] e que sejam também socorridos os officiaes e soldados que servirem na Parahiba, emquanto naquella praça não ouver rendimento da faz ${ }^{a}$ de Vmgde.” ${ }^{27}$ No ano de 1657, os oficiais da Câmara e povo da Paraíba pediam que os seiscentos soldados de presídio existentes na Paraíba, enviados de Pernambuco, fossem sustentados por esta capitania, já que não tinham rendimento bastante em razão da situação de pobreza provocada pela guerra holandesa. ${ }^{28}$ Em 1661, o capitão-mor da Paraíba, Matias de Albuquerque Maranhão, solicitava que quatro companhias de infantaria fossem providas e assistidas por Pernambuco, enquanto a Paraíba não possuísse rendimentos suficientes. ${ }^{29} \mathrm{O}$ capitão-mor João do Rego Barros, no ano de 1663, também solicitava que "da fazenda Real da Cappitania de Pernambuquo seja socorrida esta praça per faltarem nella as rendas de Vmagde pella grande limitação destes moradores nam poderem cultivar as suas fazendas." 30

A situação de dependência arrasta-se pelo século XVIII, especialmente a partir de 1723, quando, por decreto real, é estabelecido que o recolhimento da dízima, imposto que correspondia à cobrança de $10 \%$ dos bens importados, se fizesse junto com a dízima de Pernambuco, em um só contrato. Independentemente do valor alcançado na arrematação, a provedoria pernambucana ficava responsável por remeter o montante de 20 mil cruzados (oito contos de réis) para a congênere paraibana (MENEZES, 2005, p. 152). A total subordinação da Paraíba é consagrada em 1755, quando é anexada, por longos 44 anos, à capitania de Pernambuco.

\footnotetext{
${ }^{26}$ AHU_ACL_CU_014, Cx. 4, D. 329.Carta do capitão-mor da Paraíba, João da Maia da Gama, ao rei D. João V 27/5/1712.

27 AHU_ACL_CU_014, Cx. 1, D. 38. Consulta do Conselho Ultramarino, ao rei D. João IV 21/4/1655.

28 AHU_ACL_CU_014, Cx. 1, D. 40. Consulta do Conselho Ultramarino, ao rei D. Afonso VI 12/7/1657.

29 AHU_ACL_CU_014, Cx. 1, D. 47. Consulta (cópia) do Conselho Ultramarino, à rainha regente D. Luísa de Gusmão 12/11/1661.

30 AHU_ACL_CU_014, Cx. 1, D. 54.. Cara do capitão-mor da Paraíba, João do Rego Barros, ao rei [D. Afonso VI] 21/3/1663.
} 
Voltando ao caso da arrematação dos dízimos, o contrato firmou-se na forma despachada por João da Maia. Contudo, a resolução tomada pelo governador não agradou Salvador Quaresma Dourado, o provedor da Fazenda da Paraíba, gestor, por excelência, das receitas e da arrecadação tributária. O atrito pode ser vislumbrado na representação que o provedor fez ao rei, dando conta do preço e condição com que se havia arrematado o contrato dos dízimos ao empreiteiro, na qual asseverou que o negócio contribuiu para o prejuízo da demora do pagamento dos filhos da folha, termo atribuído a todos os funcionários eclesiásticos, civis e militares que recebiam remuneração da Fazenda Real. Representação com “menos verdade”, na concepção de João da Maia. Para ele, o prejuízo poderia ser evitado pelo próprio provedor, caso ele fizesse sua obrigação e cobrasse todas as dívidas vencidas e arrematadas com fiança, provenientes de contratadores e rendeiros, as quais deveriam ser pagas na então presente frota, que havia chegado a outubro de $1711 .{ }^{31}$

João da Maia chegou a arrolar as dívidas vencidas que deveriam ser cobradas, a fim de que se evitasse o atraso do pagamento dos filhos da folha:

estes tinhão com que se pagar na chegada da frota com o quartel de asucar de 3 mil cruz. ${ }^{\text {os }}$ q nesse tempo havia de pagar o contratador Antonio de Souza, e com hum conto, e sette centos mil reis q a chegada da mesma frota, havia de pagar o contratador Joseph Freire Leitão, e com 3 mil cruzados do quartel de asucar q havia de pagar o contratador Antonio Affonço, e com hum conto de reis q havião de pagar os rendr. ${ }^{\text {os }}$ do Engenho podre, e do Engenho $S^{\text {to }}$ Andre por conta da divida do Almoxarife Luis de Mendonça, alem de tres, ou quatro mil cruzados de atrazados, q se havião de cobrar de Joseph Freire Leitão, e outros tantos de Gaspar Achioli. ${ }^{32}$

Postas suas razões, o governador encerrou a aludida carta declarando: "mandei arematar [o

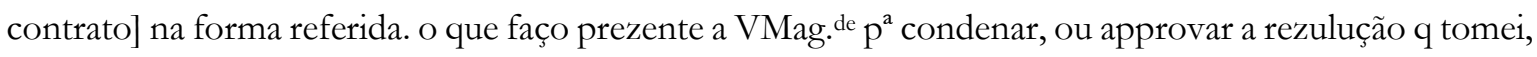
e mandar o q for servido." 33 Como resposta, receberia o descontentamento da Coroa. É o que afirma Salvador Quaresma Dourado, em troca de correspondências com o reino, quando aponta possuir o referido contrato condições que haviam sido reprovadas pelo rei. ${ }^{34}$

Mais uma vez notamos que João da Maia, antecipando-se à deliberação do centro, agiu sem sua prévia anuência. Como indicou o Procurador da Coroa, em caso de alteração na forma de arrematação dos contratos, a autorização régia era esperada. Pouco tempo atrás, a 29 de novembro de 1710, o próprio governador já havia sido advertido disso, por carta régia, que determinava: "não haveis de arematar [o contrato dos dízimos] sem primr ${ }^{\circ}$ me dares conta e esperar a minha aprovação."35 Entretanto, João da Maia optou por ignorar a recomendação nesta arrematação e na seguinte.

$\mathrm{Na}$ arrematação do contrato dos dízimos de 1712, o governador proporia outra inovação. Em 20 de abril do mesmo ano, João da Maia mandou ao provedor da Fazenda da Paraíba a ordem para pôr

\footnotetext{
31 AHU_ACL_CU_014, Cx. 4, D. 329. Carta do capitão-mor da Paraíba, João da Maia da Gama, ao rei D. João V 27/5/1712. 32 AHU_ACL_CU_014, Cx. 4, D. 329. Carta do capitão-mor da Paraíba, João da Maia da Gama, ao rei D. João V 27/5/1712.

33 AHU_ACL_CU_014, Cx. 4, D. 329. Carta do capitão-mor da Paraíba, João da Maia da Gama, ao rei D. João V 27/5/1712.

34 AHU_ACL_CU_014, Cx. 5, D. 339. Carta do [provedor da Fazenda Real], Salvador Quaresma Dourado, ao rei [D. João V] 18/9/1713.

35 AHU_ACL_CU_014, Cx. 4, D. 332. Carta do [capitão-mor da Paraíba], João da Maia da Gama, ao rei [D. João V] 17/6/1712.
} 
o contrato na praça, o qual correu até 17 de junho, sem passar do lanço de 9 mil cruzados. Seguro de que poderia fazer aumentar o valor do contrato, ordenou que o provedor o pusesse novamente na praça. ${ }^{36}$

No entanto, o governador não dispunha de licença régia para prolongar o prazo da arrematação. O procedimento previsto impunha que o capitão-mor prestasse conta à Coroa do lanço alcançado - no caso os 9 mil cruzados - e aguardasse a sua resposta para saber se deveria ou não arrematar o contrato por aquela determinada quantia. Não foi o que fez João da Maia.

Prolongou, por sua conta, o edital. E apontou o motivo. Como já corria o mês de junho e em agosto começava a vigorar o ano do contrato do dízimo para o açúcar, "se não podia esperar a rezolução de VMag. de." Na verdade, o governador havia retardado a abertura do processo em função de não haver "lançador senão de Junho por diante athe o fim de Julho, por q querem ver primeiro como corre o ano, e como sessem a canna, $\mathrm{p}^{\mathrm{a}}$ conforme a conveniencia q prometer, lançarem." 37

Contudo, as condições do contrato eram inusitadas. O edital anunciava uma inovação na forma de pagamento:

quem quizer arematar o contracto obrigando se a pagar toda a importância delle a dinhr..$^{\circ}$ pagará o quartel de dinhr. ${ }^{\circ}$ na forma costumada $\mathrm{p}^{\mathrm{a}}$ satisfação dos filhos da folha, e q os dous quartéis q se costumavão pagar em faz. da e em asucar, pagando o dinhr. ${ }^{\circ}$, se lhe fará espera de hu anno, ou de hua frota acabado o anno do seu contracto. ${ }^{38}$

Tal condição - de estender aos contratadores que pagassem em dinheiro o período de pagamento do contrato por dois anos - não era prevista pela Coroa. Sendo assim, João da Maia tentou convencer o rei de que a extensão do prazo poderia prevenir o surgimento de novas dívidas atrasadas. Situação habitual nas arrematações. De acordo com o capitão-mor, os pagamentos dos contratos do dízimo do açúcar referentes aos anos de 1707, 1708 e 1710 - arrematados aos mesmos contratadores - estavam atrasados, "e estão por pagar, e estarão mais annos, e sem as condições de pagarem a dinhr. ${ }^{\text {o tem esperas }}$ de tres e quatro annos, e VMag. de duvida fazer lhe a espera de dous annos, ou de hua frota.”39

Todavia, sua alegação pareceu não convencer o Conselho Ultramarino. A respeito dessa matéria, os conselheiros entenderam que o capitão-mor havia excedido a forma costumada nas arrematações, obrigando o provedor da Fazenda que a fizesse da referida forma. Recomendaram, ainda, que era necessário ouvir o dito provedor, a fim de saber a conta que dera neste particular. ${ }^{40}$

Ainda no tocante à arrecadação de impostos, em 1713, a Coroa criou, em todo o Brasil, um tributo de $10 \%$ sobre as fazendas importadas. A novidade foi mal recebida em toda a colônia. Afinal, como bem definiu o procurador da Fazenda, “os tributos são odiosos aos povos." Em virtude da

\footnotetext{
36 AHU_ACL_CU_014, Cx. 4, D. 332. Carta do [capitão-mor da Paraíba], João da Maia da Gama, ao rei [D. João V] 17/6/1712. 37 AHU_ACL_CU_014, Cx. 4, D. 332. Carta do [capitão-mor da Paraíba], João da Maia da Gama, ao rei [D. João V] 17/6/1712. 38 AHU_ACL_CU_014, Cx. 4, D. 332. Carta do [capitão-mor da Paraíba], João da Maia da Gama, ao rei [D. João V] 17/6/1712. 39 AHU_ACL_CU_014, Cx. 4, D. 332. Carta do [capitão-mor da Paraíba], João da Maia da Gama, ao rei [D. João V] 17/6/1712.

${ }^{40}$ AHU_ACL_CU_014, Cx. 4, D. 332. Carta do [capitão-mor da Paraíba], João da Maia da Gama, ao rei [D. João V] 17/6/1712.
} 
resistência oferecida pelos moradores da Paraíba, João da Maia empenhou-se para fazê-los aceitarem o imposto, razão pela qual mereceu elogios do procurador da Fazenda e do Conselho Ultramarino, os quais apontaram que se deveria mandar agradecer ao capitão-mor. ${ }^{41}$

Na mesma ocasião, o procurador da Fazenda - seguido pelo Conselho Ultramarino - orientou que se mandasse desaprovar a conduta do provedor da Fazenda da Paraíba pela má arrecadação na capitania e que lhe ordenasse procedesse à cobrança das dívidas da Fazenda Real, a fim de que se pudesse pagar os soldados, sem a necessidade de desviar os rendimentos da dízima. Como vimos anteriormente, em 1712, João da Maia já havia recomendado que Salvador Quaresma Dourado cobrasse todas as dívidas atrasadas a fim de satisfazer o pagamento dos filhos da folha. A relação entre o capitão-mor e o provedor da Paraíba mais uma vez não se mostrou amistosa. A respeito da arrecadação do tributo sobre as fazendas, o procurador da Fazenda relatou que "do seu [Salvador Quaresma] zêlo conhece o governador desconfiança." 42

Esse não foi o único episódio em que a suspeição foi lançada sobre o provedor. No ano de 1712, a Coroa ordenou a João da Maia que enviasse uma declaração dos últimos dez anos de todas as letras e efeitos que da Paraíba se remeteram ao Conselho Ultramarino, constando dia, mês e ano em que se passaram, as folhas dos livros da receita em que se carregaram e a pessoa por quem foram feitas e assinadas. 43

$\mathrm{Na}$ resposta dada dois anos mais tarde, o governador exprimiu sua perplexidade para dar cumprimento à ordem, pois inexistia livro em que se registrassem as letras que se passavam para o reino, não se achando declaração delas nem nos livros da Fazenda Real. Para satisfazer a determinação, João da Maia teve que recorrer às terceiras vias que ficavam em poder dos almoxarifes, sem, contudo, nelas haver a clareza devida. Pairavam ainda outras desconfianças nos negócios da Fazenda: certas despesas que se faziam, das quais o governador não tinha conhecimento e alegava ser preciso dar conta; e alguns "requerim ${ }^{\text {tos }}$ dos officiaes da Faz ${ }^{\text {da }}$ com o contrario do q consta dos dos livros." 44

Em face da desorganização dos livros da fazenda e da pouca transparência observada nos atos do provedor, João da Maia disparou: “vi a pouca e má forma q aqui havia, nas couzas da Fazenda Real". Insatisfeito, reconhecia que o que enviava ao reino "ainda não he o q basta." 45

Em 1718, temos outro exemplo da falta de controle e de abusos observados na administração da Fazenda. Como visto anteriormente, nesse ano, os soldados da infantaria relataram que entravam no quinto ano de atraso dos seus soldos, "sabendosse que os apadrinhados estão enteirados, do que se lhes devia e os mais padecem.” Em função disso, fizeram uma petição à Coroa solicitando o exame dos rendimentos do subsídio do açúcar - tributo arrecadado para o pagamento das tropas - dos anos

${ }^{41}$ DHBN, vol. XCVIII, p. 170. Carta do capitão-mor da Paraíba, João da Maia da Gama a Vossa Majestade 13/2/1713.

${ }^{42}$ DHBN, vol. XCVIII, p. 170-1. Carta do capitão-mor da Paraíba, João da Maia da Gama a Vossa Majestade 13/2/1713.

${ }^{43}$ AHU_ACL_CU_014, Cx. 5, D. 341. Carta do capitão-mor da Paraíba, João da Maia da Gama, ao rei [D. João V] 13/4/1714.

${ }^{44}$ AHU_ACL_CU_014, Cx. 5, D. 341. Carta do capitão-mor da Paraíba, João da Maia da Gama, ao rei [D. João V] 13/4/1714.

45 AHU_ACL_CU_014, Cx. 5, D. 341. Carta do capitão-mor da Paraíba, João da Maia da Gama, ao rei [D. João V] 13/4/1714. 
passados, a fim de que se repartissem igualmente seus efeitos para satisfazerem as necessidades dos suplicantes. De acordo com os soldados, o problema havia se originado após a transferência da cobrança do referido imposto passar da alçada da Câmara para a Fazenda da capitania. ${ }^{46}$

A respeito da matéria, João da Maia, nessa altura ex-governador da Paraíba e já residente na corte, foi consultado pelo Conselho Ultramarino em 1720. João da Maia lançou uma dúvida sobre a quantidade de soldados e de anos que declaravam não ter recebido, supondo que o máximo de atraso nos soldos era de dois anos, e a muitos nem isso se devia, em função de empréstimos ou adiantamentos a "alguns inclinados e feiçoados ou amigos."

A confusão se devia ao fato de o provedor comandar, através de suas ordens ou do próprio governador, o direito de pagar a muitos soldados e oficiais, sem realizar o devido registro. ${ }^{48}$ Segundo Menezes (2005, p. 107), o registro dos "pés das listas", ou "livro de mostras", onde constavam os nomes daqueles que haviam recebido o pagamento ou o adiantamento, era feito de tal forma que, às vezes, tonava-se impossível inferir quem já havia sido contemplado. Daí a possibilidade de um soldado, alegando não ter recebido, ganhar o soldo mais de uma vez. Eis a dúvida aventada por João da Maia.

Anos depois, João da Maia, em seu diário de viagem de regresso ao reino, publicado por Oliveira Martins $^{49}$, reiteraria a situação de desordem e abusos reinantes na provedoria da Paraíba. No ano de 1730, o ex-governador relatou, em seu diário de viagem de regresso para o reino, a desorganização encontrada quando retornou, em 1729, à capitania que governara. Mais uma vez, João da Maia colocaria à prova a gestão de Salvador Quaresma Dourado, que continuava a frente do órgão fazendário:

A Fazenda de S. Mag. de a achei tratada sem a pureza devida e sem o zello, e inteireza com que eu a tinha deixado, e m. ${ }^{\text {to }}$ pudera dizer nesta matéria e sô digo que com o virem de Pern. ${ }^{\text {co }} 20$ mil cruzados [da dízima] todos os annos o que não havia no meu tempo, hâ m.tos queixosos porque os que podem e tem jurisdição são pagos adiantados, não são como e que quando acabava me devião seis annos de soldo, e me foi necescario thomar nos Eng. ${ }^{\text {os }}$ os dividas de V. Mag. ${ }^{\text {de }}$ para satisfação do meu soldo no que não tenho lucrado nada, e perdido $\mathrm{mt}^{\circ}{ }^{\circ}$ com estes sete annos de seca, sem embargo da grande despesa que fis.

Hâ sete annos que se não thoma contas ao Almox..$^{\mathrm{e}}$ e hâ outros tantos q. se não fas folha,e se vay pagando, ou dando dinheiro por portarias ou brevais do Provedor e conta dos seus ordenados, e dos mesmos off. es e dis o Almox..$^{\text {e }}$ que como senão faz folha não sabe o que cada hum tem de ordenado.

E sobre as contas do Almox..$^{\mathrm{e}}$ que morreo e dos pagamentos que se fazião quando elle estava sego, ouvi bastante (MARTINS, 1944, v. 2, p. 113).

Conforme aponta Menezes, os rumos da administração do órgão só sofreriam uma mudança no ano de 1733, quando da morte de Salvador Quaresma Dourado, último proprietário da provedoria da Fazenda. ${ }^{50}$ Para o autor, " o infortúnio do provedor possibilitou o ingresso trienal de provedores letrados,

46 AHU_ACL_CU_014, Cx. 5, D. 366. Consulta do Conselho Ultramarino, ao rei D. João V 16/5/1719.

47 AHU_ACL_CU_014, Cx. 5, D. 366. Consulta do Conselho Ultramarino, ao rei D. João V 16/5/1719.

48 AHU_ACL_CU_014, Cx. 5, D. 362. Carta do [provedor da Fazenda Real], Salvador Quaresma Dourado, ao rei [D. João V] $12 / 8 / 1718$.

49 O "Diário de viagem de regresso para o reino, de João da Maia da Gama, e de inspecção das barras dos rios do Maranhão e das capitanias do Norte, em 1728”, está reproduzido, na íntegra, no segundo volume da obra de Oliveira Martins, Um herói esquecido (João da Maia da Gama) (MARTINS, 1944).

50 Salvador Quaresma Dourado foi provedor proprietário da fazenda paraibana ao longo de 50 anos (1683-1733). 
mais adaptados aos princípios burocráticos, contribuindo para a limitação de uma série de vícios e abusos praticados pelos oficiais ali lotados" (MENEZES, 2005, p. 243).

\section{CONSIDERAÇÕES FINAIS}

Em 1708, ao ingressar na Paraíba, João da Maia da Gama deparou-se com uma capitania em crise. Durante sua gestão (1708-1717), o capitão-mor e governador tentou reverter esse decadente quadro econômico. No âmbito fazendário, algumas medidas foram engendradas para recuperar a arrecadação da capitania. Combateu a sonegação de impostos nos contratos dos dízimos e articulou arrematações, visando aumentar as rendas da Fazenda Real. Nem sempre fiel às determinações da Coroa e, por vezes, antecipando-se às suas ordens, ia "pondo o remédio que podia."

Exceder-se no exercício de seu cargo parece ter sido prática costumeira do governador João da Maia, como pudemos observar nesses processos de arrematação dos dízimos. Confrontando suas atitudes com as ordens e legislações régias, percebemos que o capitão-mor não cumpria fielmente as diretrizes impostas pelo poder central. Desobedecendo a certas determinações, ignorando outras, o governador inovava e acomodava obrigações que lhe eram delegadas.

Afinal, como afirma Souza (2012, p. 40), "as decisões emanadas do poder central em Lisboa, longe de serem plenamente aplicadas, são matizadas e modificadas no âmbito local pelos poderes mais próximos." Nesse sentido, o espaço colonial é marcado pela negociação. As autoridades coloniais flexibilizavam as determinações impostas por Portugal, ao levarem em consideração as especificidades locais. As idiossincrasias pessoais, as condições econômicas, sociais e demográficas prevalecentes numa localidade podiam contribuir para vários graus de acomodação na interpretação das diretrizes metropolitanas por parte dos governantes.

Como indica Hespanha (2010), os governadores ultramarinos gozavam de uma grande autonomia. Atuavam em um mundo estranho, em mudança, diferente do mundo estabilizado da política dos reinos europeus, onde a justiça e o governo estavam enraizados em tradições estáveis e duradouras, formalizadas em processos e fórmulas fixados pelo tempo. Além dos poderes que lhe eram confiados, somava-se o fato de que estes oficiais "estavam isolados da fonte do poder [...], tendo necessidade de resolver sem ter de esperar a demorada resposta às suas demoradas perguntas" (HESPANHA, 2010, p. 175).

Mesmo que, no caso da Paraíba, as viagens não fossem tão longas, ainda assim demoravam alguns meses, impossibilitando que certos pleitos fossem prontamente resolvidos com o respaldo régio. O próprio João da Maia da Gama nos atestou isso. Um misto de dinamismo pessoal e limitação da comunicação dentro do império alargava sua autonomia.

Todavia, a autonomia desfrutada por João da Maia não confrontava com seu papel de guardião dos desígnios régios nas conquistas. Por isso, enquanto durou seu governo, embora tenha sido algumas vezes advertido de certos excessos, de um modo geral, prevaleceu a aprovação do rei e do Conselho 
Ultramarino em relação à sua conduta à frente da Paraíba. Um indício que ratifica tal aprovação é o longo período no qual ele governou a capitania da Paraíba: três triênios. Ademais, adiante the foi concedido o governo do Estado do Grão-Pará e Maranhão, em 1722, certamente em virtude dos seus serviços prestados na Paraíba, um espaço bem mais complexo e extenso do que a pequena Paraíba, o que mostra que João da Maia continuava um homem de confiança da Coroa.

\section{FONTES MANUSCRITAS:}

Arquivo Histórico Ultramarino. Manuscritos Avulsos da Capitania da Paraíba:

AHU_ACL_CU_014, Cx. 4, D. 302.

AHU_ACL_CU_014, Cx. 4, D. 323.

AHU_ACL_CU_014, Cx. 4, D. 329.

AHU_ACL_CU_014, Cx. 4, D. 332.

AHU_ACL_CU_014, Cx. 5, D. 339.

AHU_ACL_CU_014, Cx. 5, D. 341.

AHU_ACL_CU_014, Cx. 5, D. 342.

AHU_ACL_CU_014, Cx. 5, D. 353.

AHU_ACL_CU_014, Cx. 5, D. 360.

AHU_ACL_CU_014, Cx. 5, D. 362.

AHU_ACL_CU_014, Cx. 5, D. 366.

\section{Anais da Biblioteca Nacional}

ABN, vol. XXVIII, p. 287. Ordem régia 4/2/1711,.

\section{Documentos Históricos da Biblioteca Nacional}

DHBN, vol. XCVIII, p. 170-2. Carta do capitão-mor da Paraíba, João da Maia da Gama a Vossa Majestade sôbre ordem que recebera para convencer os moradores a aceitarem o tributo de $10 \%$ em tôdas as fazendas que entrarem na Alfândega 13/2/1713,

\section{REFERÊNCIAS}

BOXER, C. R. O Império Marítimo Português, 1415-1825. São Paulo: Companhia das Letras, 2010.

CARRARA, A. A. A administração dos contratos da capitania de Minas: o contratador João Rodrigues de Macedo, 1775-1807. América Latina en la historia económica, Cidade do México, n. 35, p. 31-52, enerojunio 2011. Disponível em: http://alhe.mora.edu.mx/index.php/ALHE/article/view/458/686. Acesso em: 28 ago. 2020.

HESPANHA, A. M. A constituição do Império português. Revisão de alguns enviesamentos correntes. In: FRAGOSO, J.; GOUVÊA, M. de F. S.; BICALHO, M. F. B. (org). O Antigo Regime nos trópicos: a dinâmica imperial portuguesa (séculos XVI-XVIII). Rio de Janeiro: Civilização Brasileira, 2010, p. 163188.

LOPES, G. A. A Fênix e a conjuntura atlântica: açúcar e tráfico de escravos em Pernambuco na segunda metade do século XVII. Portuguese Studies Revien, Peterborough (Canadá), v. 1, n. 20, p. 1-35, 2012.

MARTINS, F. A. O. Um herói esquecido (João da Maia da Gama). Lisboa: Agência Geral das Colônias, 1944. $2 \mathrm{v}$. 
MELLO, E. C. A fronda dos mazombos: nobres contra mascates. Pernambuco, 1666-1715. São Paulo: Editora 34, 2003.

MENEZES, M. V. Colonialismo em ação: fiscalismo, economia e sociedade na Capitania da Paraíba (16471755). Tese (Doutorado em História Econômica) - Universidade de São Paulo, São Paulo, 2005.

MENEZES, M. V. Negros e indígenas na economia da Paraíba (1654-1755). In: ROCHA, S. P. da; FONSECA, I. da S. (org.). População Negra na Paraíba: educação, história e política. v. 1. Campina Grande: Ed. da UFCG, 2010. p. 41-54.

OSÓRIO, H. As elites econômicas e a arrematação dos contratos reais: o exemplo do Rio Grande do Sul (século XVIII). In: FRAGOSO, J.; GOUVÊA, M. de F. S.; BICALHO, M. F. B. (org.). O Antigo Regime nos trópicos: a dinâmica imperial portuguesa (séculos XVI-XVIII). Rio de Janeiro: Civilização Brasileira, 2010. p. 107-137.

PALACIOS, G. Campesinato e escravidão no Brasil: agricultores livres e pobres na Capitania Geral de Pernambuco (1700-1817). Brasília: Ed. da UNB, 2004.

PRADO JR., C. Formação do Brasil Contemporâneo. São Paulo: Brasiliense; Publifolha. 2000. (Col. Grandes Nomes do Pensamento Brasileiro).

SCHWARTZ, S. B. Segredos Internos: engenhos e escravos na sociedade colonial, 1550-1835. São Paulo: Companhia das Letras, 2011.

SOUZA, G. F. C. Tratos e mofatras: o grupo mercantil do Recife colonial (c. 1654-c. 1759). Recife: Ed. Universitária UFPE, 2012.

Data de submissão: 28/09/2020

Data de aprovação: $13 / 10 / 2020$ 